\title{
MANAJEMEN TELEVISI LOKAL: KEGAMANGAN YANG WAJAR
}

\author{
Kartika Bayu Primasanti \\ Program Studi Ilmu Komunikasi, Universitas Kristen Petra Surabaya \\ Email: primasanti@petra.ac.id
}

\begin{abstract}
This paper reports on observation of how local television industries manage their aspects, such as conceptual aspect, human resources aspect, and technical aspect. This paper highlights the uncertainty of local television industry management on those aspects as something common related to economic and politic context. From 'market perspective', this paper concludes some important strategies which aim to help the survival of local television industries. Instead of competing with Jakartas television, local television should prepare for understanding and creating qualified local content, maintaining good internship program to solve human resource problems, and improving production of qualified program within limited technical equipments. A good management of local television industries in those aspects helps them to be a strategic tool in disseminating democratization within broadcasting media.
\end{abstract}

Keywords: Local television, media management, concept, human resource, technical management.

\section{PENDAHULUAN}

Pada awal kemunculannya, televisi lokal di Indonesia dipandang sebelah mata. Beberapa pendapat memprediksi bahwa televisi lokal hanya akan menjadi replika dari stasiun televisi swasta yang jakartasentris ${ }^{1}$. Selain itu, argumen mengenai persaingan yang tidak seimbang dengan televisi Jakarta, berikut apatisme dari beberapa pihak, memicu polemik mengenai eksistensi televisi lokal di Indoensia. Gulung tikarnya Tugu TV dari Jogjakarta menjadi salah satu bukti kecil atas ketidaksiapan industri televisi lokal pada waktu itu. Ada yang mengatakan, industri lokal terlalu terburu-buru dalam meresponi UU Penyiaran (No 32/ 2002) serta UU Otonomi Daerah (22/ 1999) ${ }^{2}$. Padahal untuk menyiapkan sebuah industri penyiaran (televisi) memerlukan sumber daya yang tidak remeh. Namun, opini skeptis terhadap televisi lokal ini lambat laun sirna. Setelah ramai dikaji dalam berbagai diskursus, banyak pihak yang 'kesengsem' dengan potensi industri televisi lokal, baik bagi tujuan komersial maupun ideologi. Demikian hingga tahun 2005 lalu, situs resmi

\footnotetext{
${ }^{1}$ Pendapat mengenai TV swasta nasional yang selama ini cenderung jakartasentris diungkapkan dalam beberapa tulisan, di antaranya: Agus Sudibyo, Ekonomi Politik Media Penyiaran, LKIS, Jakarta, 2004, hal. 100; Ashadi Siregar, Menyingkap Media Penyiaran: Membaca Televisi, Melihat Radio, LP3Y, Yogyakarta, 2001, hal 34.

${ }^{2}$ Kedua UU ini merupakan peluru yang dilempar oleh pemerintah untuk menstimuli demokratisasi melalui penyiaran.
} 
Asosiasi Televisi Lokal Indonesia (ATVLI) mencatat 65 stasiun televisi lokal telah beroperasi di Indonesia ${ }^{3}$. Khusus di Surabaya, sampai tahun 2009 lalu terdaftar beberapa stasiun televisi yang sudah mulai beroperasi dengan akselerasi yang matang, seperti: JTV, SBO TV, Arek TV, dan Spacetoon. Bukan hanya secara kuantitas, secara isi pun stasiun televisi ini mengalami peningkatan. Programprogamnya menunjukkan variasi dan mulai diproduksi secara mandiri ${ }^{4}$. Suatu kabar menggembirakan bagi demokratisasi penyiaran.

Namun, pertumbuhan yang pesat tidak lantas menjadi jaminan bahwa para pengelola industri televisi lokal telah menerapkan manajemen media dengan baik. Apalagi perubahan yang berasal dari faktor eksogen (faktor luar), seperti regulasi, kebijakan, konsumsi, teknologi selalu menuntut kecepatan yang sepadan dari industri televisi (Lucy Kung, 2008: 6). Pengalaman penulis berinteraksi dengan berbagai laporan mahasiswa yang melakukan magang kerja di televisi lokal, khususnya di Jawa Timur, menyiratkan kegamangan dalam manajemen televisi lokal. Jika boleh dirangkum dalam bahasa sederhana, beberapa problem ini di antaranya berkaitan dengan isi siaran yang monoton, pemilihan narasumber yang kurang tepat, sumber daya manusia (penyiar) yang tidak terlatih, peran pekerja televisi yang acapkali merangkap, tidak adanya sistem training yang memadai, dan terbatasnya peralatan teknis. Jika persoalan yang berkaitan ini tidak dikelola dengan baik, secara otomatis akan berdampak pada output dari televisi lokal (Lucy Kung, 2008: 6). Hal ini menyebabkan tidak maksimalnya fungsi televisi lokal untuk memperkuat kapasitas lokal.

Sejauh penelusuran awal, penulis menemukan tidak banyak yang menaruh perhatian pada problematika manajemen televisi lokal. Beberapa kajian berkonsentrasi pada konten dan pemasaran pada industri televisi lokal. Tidak berlebihan jika manajemen televisi lokal menjadi fokus kajian pada tulisan ini. Gambaran mengenai manajemen televisi lokal ini akan berfaedah bagi pekerja industri maupun pemerintah untuk saling melengkapi mendekati konsep ideal yang dicita-citakan. Secara sederhana, tulisan ini akan mengkaji manajemen televisi lokal.

\section{METODE}

Dalam kajian ini, penulis banyak mengambil contoh kasus televisi lokal Jawa Timur, seperti JTV, SBO TV, Arek TV, dan Batu TV. Pengambilan data dilakukan melalui studi dokumentasi dari beberapa laporan pengamatan mahasiswa yang melakukan magang di stasiun televisi lokal di Jawa Timur serta beberapa referensi bacaan. Melalui kajian ini, penulis ingin menunjukkan gambaran manajemen televisi lokal di Indonesia berikut perspektif apa yang mendominasinya. Tulisan ini akan diawali dengan kerangka berpikir tentang manajemen media penyiaran, dilanjutkan

\footnotetext{
${ }^{3}$ Data diambil dari artikel Film Impor, Bahasa Lokal dari majalah Behind The Scene, Bulan Agustus, 2005 dalam Kartika Bayu Primasanti, Rekonsolidasi Potensi Televisi Lokal dalam Penguatan Kapasitas Lokal, Fisipol UGM, Yogyakarta, 2007.

${ }^{4}$ Pada awal-awal berdirinya, kebanyakan stasiun televisi lokal bersindikasi dengan stasiun televisi swasta lain dalam hal program; saat ini hampir semua program televisi lokal diproduksi secara inhouse (mandiri).
} 
dengan paparan mengenai manajemen televisi lokal berikut uraian rekomendasi, serta kesimpulan.

\section{PEMBAHASAN}

\section{Manajemen Media Penyiaran}

Tulisan-tulisan mengenai televisi lokal didominasi kajian tentang konten dan kiprah televisi lokal dalam penguatan kapasitas lokal. Sementara, keduanya tidak akan menampakkan output memuaskan jika tidak disertai dengan kerja manajemen produksi yang handal. Padahal, jika manajemen tidak dilakukan dengan prinsipprinsip pengelolaan media yang tepat, media justru akan menjadi industri bisnis yang profit oriented dari pada organisasi yang bervisi demokratisasi. Douglas Kellner mencatatnya sebagai dua kutub kontradiksi yang dimiliki industry televisi, di satu sisi televisi dapat memproduksi status kuo dari power tertentu; di sisi lain televisi menunjang perubahan dan reformasi sosial (1990: 6).

Kajian manajemen media dengan demikian tidak sama dengan kajian manajemen pada umumnya. Seperti yang diungkapkan Lucy Kung, "Indeed the subject of media management has in the main been approached from media-related disciplines that are not grounded in the study of management and organizations (2008: 4). Cottle menambahkan bahwa kekhususan karakter pada manajemen media adalah pendekatannya yang acapkali bersifat ekonomi politik. "This field combines economics, politics, and sociology perspectives to analyse the structure of the media industries and regulatory and policy issues, looking particularly at the economic determinants, ownership structures, and political allegiances (Kung, 2008: 5). Sedangkan untuk mengkaji manajemen media ini, ada dua sudut pandang yang lahir dari pendekatannya yang bersifat ekonomi politik. Mengutip Amir Effendi Siregar, ada dua perspektif yang menjadi landasan manajemen media (massa) yaitu: otoriter atau propaganda dan pasar bebas. ${ }^{5}$ Masing-masing perspektif membawa konsekuensi pada proses produksi media, karakteristik pesan, pendanaan, kontrol, dan sasaran pembaca. Masing-masing perspektif pun membawa pengaruh pada cara pandang manajemen terhadap lingkungan usahanya.

Perspektif propaganda memberi penjelasan bahwa manajemen media memiliki tujuan tertentu. Perspektif ini melihat media memiliki orientasi pesan top-down; sebagai alat untuk merefleksikan ide pihak yang berkuasa atasnya. Contoh dari media yang dikelola dengan menggunakan perspektif propaganda adalah mediamedia partisan. ${ }^{6}$ Perspektif ini memiliki dampak pada dominasi pesan oleh sekelompok kepentingan tertentu yang menguasai media.

Bertolak belakang dengan perspektif propaganda, manajemen media dengan perspektif pasar menaruh perhatian pada orientasi komersial. Dalam perspektif ini, manajemen dituntut untuk selalu tanggap pada keinginan pasar. Manajemen harus

\footnotetext{
${ }^{5}$ Amir Effendi Siregar. 1998, Reformasi Pers Indonesia: Biarkan "Bunga" Tumbuh Di ManaMana, Suara Pembaruan, Kamis 2 Juli, Jakarta.

${ }^{6}$ Almanak Pers Indonesia. 1995. Departemen Penerangan Republik Indonesia-Masyarakat Pers dan Grafika Indonesia dalam Rahayu, Diktat Mata Kuliah Manajemen Media Massa, Fisipol UGM, Yogyakarta.
} 
mampu merefleksikan dinamika kehidupan dan kebutuhan pasar terhadap informasi. Dengan demikian, pasar sangat menentukan dinamika industri media, karenanya orientasi isi dalam perspektif ini diupayakan mewakili kepentingan konsumen untuk memberikan manfaat bagi pendidikan, hiburan, alat sosialisasi, jendela pengetahuan maupun 'agenda setting'. Para penganut perspektif ini adalah industri swasta. Memperhatikan dua perspektif ini, tentu tidak satu pun ideal bagi demokratisasi. Maka disesuaikan dengan kondisi yang terjadi di Indonesia, perspektif pasar tentu lebih sesuai digunakan untuk memotret kajian manajemen televisi lokal ini.

"Management is often considered to be a process because of its ongoing state of operation" (Albarran, 2002: 90). Demikian pernyataan Albarran mengenai manajemen media. Sementara, Wayne Mondy (1983 dalam Morissan, 2008: 128) mengatakan bahwa manajemen adalah "the process of planning, organizing, influencing, coordinated use of human and material resources". Melihat dua definisi ini, manajemen media dapat dimaknai sebagai proses merencanakan, mengorganisasikan, mempengaruhi seluruh sumber daya yang ada di dalam media untuk mencapai visi tertentu. Secara umum, teori manajemen media meliputi tiga area kompetensi, yakni: manajemen teknis, manajemen sumber daya manusia, dan manajemen konsep, ditambah dengan ketrampilan finansial dan marketing (Hersey \& Blanchard, 1996 dalam Albarran, 2002: 17). Dengan mempertimbangkan ruang lingkup kajian komunikasi, yang akan dibahas dalam kajian ini adalah manajemen konsep, sumber daya manusia, dan manajemen teknis dari media televisi. Albarran (2002: 17) mencatat Manajemen konseptual adalah mengenai pengelolaan lingkungan internal dan eksternal yang komplit. Perubahan selalu terjadi secara konstan di dalam media sehingga media harus meresponi dengan cepat. Menurut Albarran, manajemen konseptual yang baik hendaknya selalu dekat dengan beragam isu dan dapat menyelesaikan persoalan dengan efisien. Sedangkan manajemen sumber daya manusia menyangkut ketrampilan dalam pengelolaan sumber daya manusia, termasuk ketrampilan berkomunikasi secara interpersonal. Manajemen sumber daya manusia hendaknya dapat mendorong kinerja yang efektif dan menciptakan semangat untuk bekerjasama dan berpartisipasi di antara semua pekerja. Manajemen teknis berhubungan dengan pemahaman secara teknis mengenai pengoperasian teknologi dan inovasi secara konstan di dalam industri komunikasi. Hal ini mencakup pengoperasian peralatan, pengiriman sinyal, distribusi program, dan pengaplikasian komputer (Albarran, 2002: 19). Ketiga hal ini tidak dapat dipisahkan dalam sebuah manajemen media. Ketiga hal ini pula yang digunakan sebagai unit analisis untuk memotret manajemen televisi lokal dalam kajian ini.

\section{Manajemen Konseptual: Kerancuan Memahami Lokalitas}

Dalam catatan Kompas yang dikutip Asosiasi Televisi Lokal Indonesia (www.atvli.com, 2004) dikatakan bahwa tujuan pendirian televisi lokal adalah untuk menonjolkan budaya setempat. Hal ini ditegaskan pula oleh Paulus Widianto, Ketua Pansus RUU Penyiaran (www.atvli.com, 2004), dengan mengatakan bahwa fungsi dari televisi lokal adalah sebagai counter culture terhadap budaya asing yang saat ini sudah merajalela di televisi nasional. Televisi lokal dianggap sebagai titik per- 
wujudan perubahan paradigma yang sebelumnya sentralistik dan didominasi oleh segelintir kepentingan. Tabel 1 menerangkan karakteristik televisi lokal di Indonesia.

Tabel 1. Perbedaan Televisi Lokal dan Televisi Jakarta

\begin{tabular}{clll}
\hline No & \multicolumn{1}{c}{ Isu } & \multicolumn{1}{c}{ Industri Televisi Lokal } & \multicolumn{1}{c}{ Industri Tlevisi Jakarta } \\
\hline 1 & Pembagian Kanal & Kanal milik lokal & Kanal digunakan Jakarta \\
2 & Kepentingan Ekonomi & Kue iklan nasional dan lokal & Kue iklan nasional \\
3 & Kepentingan Politis & Kekhasan Televisi Lokal & $\begin{array}{l}\text { Program Populer untuk menarik } \\
\text { pengiklan }\end{array}$ \\
\hline
\end{tabular}

Sumber: Primasanti, 2008: 95

Dari tabel tersebut dapat dibaca bahwa televisi lokal diidealkan untuk memiliki kekuatan dalam rangka menonjolkan kekhasan lokal. Wacana ini menjadi penting untuk mengingatkan kembali bahwa fungsi televisi lokal tidak lain adalah untuk menyiarkan kekhasan lokal dan melawan dominasi kekuasaan segelintir pihak. Hal ini jelas harus dipahami oleh pihak manajemen industri televisi lokal karena acapkali, oleh persaingan industri televisi, televisi lokal justru berperan sebagai industri swasta yang profit oriented semata.

Pandangan ideal ini layak menjadi standar yang baku untuk menilik praktik televisi lokal di Indonesia, khususnya dalam hal memanajemen konseptual atau konten tayangan. Dilihat dari visinya, beberapa stasiun televisi lokal di jawa timur memiliki cita-cita yang ideal berkaitan dengan visi televisi lokal mula-mula. Dari beberapa visinya, tersurat semangat mengusung budaya lokal yang kuat. JTV misalnya, hadir dengan visi "Mewujudkan budaya dan potensi ekonomi Jawa Timur yang "Satus Persen Jawa Timur" (Jawa Timur yang sesungguhnya/ Truly Jawa Timur" (Profil JTV dalam Lina, 2009: 3). Bahkan, dalam visinya, Arek TV menyebut ingin menjadi salah satu referensi televisi lokal di Indonesia, "Arek TV menjadi perusahaan yang kuat dan sehat di bidang penyiaran televisi, dan menjadi rujukan berkembangnya televisi lokal di Jawa Timur pada khususnya dan Indonesia pada umumnya" (Profil Arek TV dalam Melissa, 2009: 15). Semangat mewujudkan konten berbasis lokal ini pun tampak pada visi SBO TV, "Meletakkan masyarakat lokal Surabaya pada posisi pertama dengan memberikan informasi melalui media untuk membantu pemirsa televisi mencapai gol dan tujuan mereka" (Profil SBO TV dalam Linda, 2009: 17). Satu lagi, yakni spacetoon yang tampil dengan visi "Sebagai media yang memberi sumbangan terhadap perkembangan anak-anak Indonesia umumnya serta Surabaya dan Jawa Timur khususnya" (Profil Spacetoon dalam Oktovani, 2009: 12). Penentuan visi yang berkonsentrasi pada lokalitas ini tampaknya telah dikerjakan dengan sempurna oleh industri televisi lokal tersebut. Persoalannya, apakah visi ini mampu dioperasionalkan dalam program-program untuk menjawab tantangan konseptual yang harus dipikirkan oleh pihak manajemen.

Albarran (2002: 18) menulis bahwa dalam hal manajemen konseptual ini, seorang manajer harus memiliki ketrampilan dalam hal merespon perubahan yang terjadi di lingkungan sekitar. "Electronic media managers must deal with a variety of issues and solve problems efficiently". Iklim persaingan yang semakin ketat di antara industri televisi lokal pun memaksa beberapa stasiun televisi lokal berinovasi mengenai konsep tayangan mereka. Beberapa televisi lokal di Surabaya sudah mulai menampakkan fokusnya pada tayangan-tayangan yang bersifat lokal. Misalnya JTV 
yang menayangkan program Back atau Berita Kocak yang berisi berita seputar Surabaya dan dibawakan dengan aksen Surabaya. Masih dalam tayangan berita, SBO TV pun mengambil inisiatif untuk menayangkan SBO 930 yang berisi beritaberita seputar Surabaya. Di Batu TV, Malang, program berita dikemas dalam tajuk Info Malang Raya yang mengupas berita-berita seputar Malang dan sekitarnya. Tabel berikut ini sebuah contoh Jam Acara Lokal di Batu TV yang mengindikasikan manajemen konsep lokal pada televisi lokal (Profil Batu TV dalam Mido, 2010).

Tabel 2. Jam Acara Batu TV

\begin{tabular}{|c|l|l|}
\hline Jam Tayang & \multicolumn{1}{|c|}{ Program } & \multicolumn{1}{c|}{ Nama Program } \\
\hline $07.00-10.00$ & SMS Chat & Zona Chatting \\
\hline $10.00-10.30$ & Kuliner & Rahasia Dapur Kita \\
\hline $10.30-11.00$ & Berita News & Info Malang Raya (Rec ) \\
\hline $12.00-13.00$ & Music & Extra Music (Video Clip) + tayang ulang liputan khusus \\
\hline $16.00-17.00$ & Kesehatan & Dialog Interaktif \\
\hline $17.00-18.00$ & Religius & $\begin{array}{l}\text { 1.Lorong Waktu } \\
\text { 2. Musik Islami }\end{array}$ \\
\hline $19.00-19.30$ & Berita / News & Info Malang Raya \\
\hline $19.30-21.00$ & Liputan khusus & Liputan Khusus \\
\hline $21.00-22.00$ & Music & Nada \& Irama, Campursari, \\
\hline $22.00-23.00$ & Acara Lokal & Wayang, dangdut, Isthigotsah dll (live) \\
\hline & & \\
\hline
\end{tabular}

Manajemen konsep yang mengacu pada lokal pun tercermin dalam programprogram hiburan yang acapkali mengangkat tema-tema lokal, seperti program wayang dan dangdut di Batu TV. Contoh lain adalah Leukoh dari Arek TV yakni program kuliner yang mengangkat tempat-tempat kuliner di sekitar Surabaya. Jika pun ada program musik, maka program tersebut dikelola dengan tetap mensyaratkan aspirasi masyarakat lokal, misalnya program music lyric yang didesain dengan tetap melibatkan interaksi dengan masyarakat lokal melalui telpon. Menurut pengamatan, program yang bernuansa lokal ini telah mendominasi tayangan-tayangan televisi lokal, khususnya di Jawa Timur.

Melalui pembacaan terhadap beberapa program televisi lokal ini terindikasi bahwa sebagian besar program yang ditayangkan oleh televisi lokal berorientasi kepada konten lokal, seperti menampilkan budaya atau seni lokal, tempat-tempat lokal, masyarakat lokal, dan kepentingan lokal tetapi dengan disesuaikan dengan kepentingan pasar. Karena sebagian besar target audiens dari televisi lokal ini adalah BC (menengah ke bawah) maka acapkali konten lokal pun menyesuaikan. Persoalannya, jika perspektif pasar mendominasi wacana konten televisi lokal maka permintaan pasar itulah yang akan dianut oleh penentu isi program siaran televisi lokal. Jika pasar televisi lokal memiliki karakter sosio dan psikografis yang belum kuat media literasinya maka hal ini dapat menjadi bumerang bagi visi televisi lokal mengangkat konten lokal yang berkualitas. Sebagai contoh, beberapa televisi lokal dalam tayangannya didominasi oleh hiburan rakyat semata dan proporsi tayangan informasinya sangat kecil. 
Tabel 3. Prosentase Program di JTV

\begin{tabular}{lc}
\hline \multicolumn{1}{c}{ Jenis Program } & Prosentase \\
\hline Berita & $35 \%$ \\
Talkshow & $6 \%$ \\
Budaya & $17,5 \%$ \\
Hiburan & $31 \%$ \\
Olah raga & $6,5 \%$ \\
Agama & $4 \%$ \\
\hline
\end{tabular}

Sumber: Company Profile JTV, 2009 dalam Lina, 2009:2

Dari tabel di atas terbaca bahwa tayangan hiburan masih mendominasi dibandingkan dengan tayangan yang lain. Bahkan, tidak disebutkan program yang bertema khusus tentang pendidikan. Padahal, jika mengacu pada perspektif pasar dalam manajemen media pun disyaratkan bahwa orientasi isi media mewakili kepentingan konsumen untuk memberikan manfaat bagi pendidikan, hiburan, alat sosialisasi, jendela pengetahuan maupun 'agenda setting'.

Jadi, betapa pun saat ini televisi lokal telah menerapkan perencanaan dan pengorganisasian konsep yang mengikuti perubahan yang disebabkan faktor eksogen komitmen manajemen untuk setia pada cita-cita mengembangkan lokalitas yang berkualitas pun harus tetap dijaga. Jika tidak, benar tesis pada skeptis pada masa lampau, televisi lokal hanya akan menjadi replika dari televisi swasta yang saat ini bersiaran secara nasional. Manajemen tidak seharusnya membiarkan konsep lokalitas dipahami dari segi geografis, sosiografis, maupun budaya yang apa adanya, melainkan berupaya untuk tidak membiarkan program-program televisi lokal menjadi seadanya. Kualitas harus tetap memimpin untuk menciptakan media literacy bagi masyarakat lokal. Jika keberagaman konten televisi lokal ini telah dikelola sedemikian rupa melalui layar televisi dan diterapkan oleh sebagian besar televisi lokal di Indonesia maka semangat demokratisasi melalui media televisi lokal pun siap didiseminasikan.

\section{Manajemen Sumber Daya: Cerdas Memberdayakan}

Employees are the most valuable asset of any organization (Albarran, 2002: 143). Pernyataan Albarran ini pun berlaku bagi organisasi televisi lokal. Konsekuensi logisnya, pemilihan sumber daya manusia yang tepat sangat dibutuhkan oleh seorang manajer untuk mengembangkan sebuah stasiun televisi yang berkualitas. Albarran mengatakan, "As new and existing position open up, managers must identify and properly select qualified new personel' (2002: 125).

Persoalan manajemen sumber daya juga menjadi dilema bagi industri televisi lokal yang berkaitan dengan kuantitas sumber daya dan kepakaran atau keahlian. Kuantitas sumber daya televisi lokal yang minim menjadi salah satu argumen ketika sebuah program televisi tampil tidak maksimal. Misalnya, beberapa kesalahan terjadi pada saat penayangan diakibatkan oleh human error. Berdasarkan laporan pengamatan yang dilakukan mahasiswa magang, human error terjadi sebagai konsekuensi minimnya sumber daya manusia. Beberapa peran terpaksa harus dirangkap oleh satu atau dua orang saja. Sebuah televisi lokal, walaupun telah memiliki struktur organisasi, acapkali masih membuat para pekerjanya merangkap 
beberapa posisi. Misalnya, satu produser dapat memproduseri beberapa program acara. Contoh lainnya, lighting man, soundman, cameraman merangkap untuk beberapa program acara. Selain berdampak pada reduksi kualitas tayangan, hal ini juga mengurangi diversity background dari para pekerja media. Sedangkan Albarran menyarankan diversitas latar belakang, ketrampilan, budaya dari para pekerja media sebagai salah satu stimulus terwujudnya keragaman isi tayangan untuk menyikapi berbagai perubahan. Seperti yang diungkapkan Albarran (2002: 135), "Because of demographic and other changes, managers in the electronic media currently encounter a diverse workforce".

Problem yang ke dua adalah penempatan personel yang tidak sesuai dengan keahliannya. Benar kata Albarran bahwa personel dalam sebuah media elektronik hendaknya berasal dari beragam latar belakang tapi hal ini akan menjadi masalah manakala tidak sesuai dengan kualifikasi yang dibutuhkan. Misalnya, pendidikan atau ketrampilan si pekerja tidak sesuai dengan kebutuhan media. Padahal menurut Albarran (2002: 123), The quality of personnel at an electronic media facility often determines its ability achieve success. Salah satu langkanya sumber daya manusia di televisi lokal ini disebabkan karena pusat-pusat pendidikan pertelevisian yang masih berpusat di Jakarta dan kota-kota besar. Beruntung, di Surabaya telah berdiri banyak institusi yang mendidik para pekerja media televisi baik secara konseptual maupun ketrampilan teknis.

Akar dari persoalan minimnya sumber daya manusia dalam industri televisi lokal ini adalah masalah keuangan dari televisi lokal itu sendiri. Dalam masa pertumbuhan dan pencarian jati dirinya, televisi lokal menuntut dana yang tidak sedikit untuk kelangsungan hidupnya. Akhirnya, kuantitas dan kualitas sumber daya manusia yang ada di dalamnya pun menjadi prioritas ke sekian dibanding orientasi pada output untuk memenuhi keinginan pasar. Padahal, sumber daya manusia dan output saling berjalinkelindan, tidak dapat dipisahkan. Ketika problem ini tercium oleh mahasiswa magang dan disarankan untuk menambah personel, pihak manajemen menolak. Solusi menambah personel dianggap tidak relevan karena akan berujung pada persoalan keuangan.

Melihat problem yang seolah tidak terpecahkan ini, ada baiknya merenungkan saran bijak dari Albarran untuk membaca potensi internship program dalam media. Menurut Albarran, "A large majority of electronic media companies offer internship opportunities through local colleges and universities" (Albarran, 2002: 134). Sayangnya, pengalaman berinteraksi dengan laporan mahasiswa magang di lapangan menunjukkan bahwa mahasiswa magang acapkali diminta untuk membantu proses-proses produksi dalam televisi lokal dengan job description yang belum jelas. Selama melakukan magang, beberapa mahasiswa melaporkan bahwa mereka hanya diberi tugas untuk memfoto copy, membuat surat-surat, mengambilkan minum, hal-hal yang tidak sesuai dengan disiplin ilmu mereka. Manajemen mengabaikan potensi internship yang seharusnya dapat menjadi solusi bagi minimnya sumber daya manusia di industri televisi lokal.

Sejatinya, ada keuntungan apabila manajemen memasukkan mahasiswa interns ini ke dalam struktur organisasi. Albarran pun menawarkan tiga ide penting untuk memfasilitasi program internship. Yang pertama adalah interns not be selected haphazardly (Albarran, 2002: 135). Para pekerja atau mahasiswa magang harus 
benar-benar dipilih melalu proses seleksi yang baik sesuai dengan fokus dan tugastugas yang dibutuhkan. Yang ke dua, interns should be evaluated similarly to other employees so the intern supervisor can point out strengths and ways to improve performance. Bagi industri, dengan adanya evaluasi bagi mahasiswa magang, dapat meningkatkan kinerja mereka dan membantu membentuk pekerja media yang handal di masa depannya. Bagi mahasiswa magang atau institusi pendidikan, langkah ini menjadikan magang sebagai tempat para calon pekerja media ditempa sehingga ketika lulus telah siap melakukan kerja media yang handal. Ke tiga, only student enrolled in an actual credit course should be allowed to intern. Kontak yang regular pun perlu dilakukan untuk melaporkan performa mahasiswa magang kepada institusi pendidikan. Jika dalam satu semester, sebuah univeritas mengadakan dua kali magang; dan jika ada lebih dari lima universitas yang menyediakan ketrampilan dalam bermedia; maka ada minimal 10 mahasiswa magang dalam satu semester. Jumlah ini sangat berarti jika industri televisi dapat memanfaatkan dengan baik. Jadi, problem sumber daya yang belum terpecahkan dalam dinamika televisi lokal dapat disiasati dengan penerimaan mahasiswa atau pekerja magang melalui perencanaan, pengorganisasian, dan evaluasi manajemen yang tepat. Jika masalah ini teratasi, secara otomatis iklim diversitas internal industri televisi sendiri telah terpenuhi sebagai modal terciptanya diversitas dalam isi media.

\section{Manajemen Teknis: Prematur bukan Masalah}

Kompetensi dalam mengelola persoalan teknis pun menjadi tuntutan penting bagi manajemen sebuah industri televisi lokal. Hal-hal teknis ini meliputi equipment operation, signal transmission, program distribution, and computer application (Albarran, 2002: 18). Hal-hal teknis inilah yang menjadi sarana sebuah televisi lokal dapat memancarkan siarannya selain telah memiliki frekuensi sesuai dengan ketentuan pemerintah. Dalam pengamatan mengenai televisi lokal di Surabaya, persoalan yang muncul dalam masalah teknis ini antara lain: kurang tersedianya infrastruktur yang memadahi dan pengelolaan penempatan personalia yang sesuai dengan ketrampilan teknis yang dimilikinya.

Menurut pengalaman mahasiswa magang di lapangan ditemukan data bahwa beberapa telvisi lokal di Jawa Timur telah memiliki peralatan teknis yang memadahi namun sebagian lainnya belum. Misalnya saja, di Batu TV, proses shooting sebuah berita dilakukan tanpa kameramen dan pengarah gaya. Menurut laporan mahasiswa yang melakukan magang kerja, proses produksi siaran berita tersebut dilakukan dengan sebuah kamera saja (Mido, 2010). Padahal untuk menciptakan sebuah program berita yang berkualitas dibutuhkan tim pengarah acara dan bagian yang memiliki spesifikasi teknis. Temuan lain menceritakan ada stasiun televisi lokal yang hanya memiliki dua kamera yang digunakan untuk seluruh program acara.

Serupa dengan persoalan sumber daya manusia, persoalan infrastruktur pun berakar pada masalah kapital industri lokal. Bagi industri televisi lokal yang merupakan konglomerasi dari media lain, hal ini tidak menjadi masalah krusial karena ada sektor lain yang menopang. Sayangnya, bagi industri televisi lokal yang independen, masalah kapital tidak dapat dihindari. Jadi, persoalan teknis ini tidak lantas menyandangkan gelar ideal atau tidaknya televisi lokal. 
Berita baiknya, studi yang dilakukan oleh Agus Sudibyo (2006: 121) membuktikan sebuah efek kejut bahwa mengoperasikan stasiun televisi ternyata tidak harus mengunakan peralatan yang serba canggih dan mahal. Sudibyo mencatat bahwa sebuah stasiun televisi dapat diupayakan oleh warga biasa, dengan tayangan-tayangan yang sangat akrab dengan kehidupan khalayak pemirsa. Hal ini sangat kontras dengan pemahaman masyarakat kebanyakan bahwa stasiun televisi selalu membutuhkan modal besar. Sesungguhnya pada titik inilah kekuatan televisi lokal menjadi nyata. Kedekatan dengan khalayak lokal menjadi potensi yang lebih besar daripada sekadar persoalan teknis. Melihat fakta kejut ini, manajemen televisi lokal baiknya menyiapkan strategi untuk menutupi kekurangannya pada masalah teknis ini dengan mengupayakan tayangan yang lebih berkualitas bagi khalayaknya.

\section{KESIMPULAN}

Manajemen televisi lokal tampaknya tidak dapat serta merta melawan kerasnya persaingan dengan televisi Jakarta yang telah mapan. Namun keberadaan televisi lokal untuk mendiseminasikan demokratisasi melalui media penyiaran tidak boleh mati. Keragaman konten dari televisi lokal yang mengangkat unsur lokalitas yang beragam dari berbagai daerah menjadi ujung tombak demokratisasi melalui media penyiaran. Idealisme mengenai lokalitas ini tercermin dalam tiga hal, yakni aspek konseptual, sumberdaya, dan teknis siaran. Dengan demikian, posisi manajemen dalam mencapai visi demokratisasi televisi lokal hendaknya diimplementasikan dalam ketiga aspek tersebut.

Pengalaman membaca beberapa laporan magang mahasiswa memberi gambaran bahwa masih ada persoalan dalam mengelola ketiga aspek tersebut. Dalam aspek konten, televisi lokal cenderung berorientasi sebagai industri swasta yang serta merta mengejar profit sehingga melupakan kodratnya sebagai televisi lokal yang membawa amanat demokratisasi. Berita baiknya, beberapa televisi lokal di Surabaya telah menerapkan manajemen konseptual dengan memperhatikan kualitas kelokalan tayangan mereka. Hal ini tercermin dari prosentase yang besar bagi tayangan yang berkonten lokal serta pelibatan khalayak lokal dalam beberapa programnya. Aspek lainnya adalah aspek sumber daya manusia. Tampaknya ada masalah krusial dalam manajemen sumber daya manusia. Akar masalah dari aspek ini adalah finansial dan kurangnya sarana edukasi khusus bagi para pekerja media di ranah lokal. Namun, hal ini dapat diatasi dengan mengelola program internship yang mendatangkan keuntungan bagi industri maupun institusi pendidikan dalam menyiapkan sumber daya manusia bagi sektor lokal. Persoalan ke tiga adalah manajemen teknis yang dikarenakan minimnya prasarana. Namun, prematurnya persiapan teknis industri televisi lokal sangat dimaklumi selama kekuatan kontennya mendapat perhatian.

Bahwa industri televisi lokal masih gamang dalam mengelola aspek-aspek pentingnya, hal ini sejatinya adalah wajar. Sejauh pengamatan yang dilakukan, industri televisi lokal tengah ataupun telah berupaya keras bertahan. Komitmen dan ketangguhan manajemen dituntut untuk merespon keadaan ini. Melalui pembacaan atas manajemen televisi lokal ini, penulis berharap pembaca memiliki sense of belonging terhadap televisi lokal. Demikian pula bagi pihak manajemen industry televisi lokal dirangsang untuk bijak dan cerdas menyikapi kegamangan yang terjadi. 
Manajemen televisi lokal yang kuat menjadi salah satu jaminan menjadikan televisi lokal alat pendiseminasi demokratisasi.

\section{DAFTARPUSTAKA}

Albarran, Alan B. 2002. Management of Electronic Media. USA: Wadsworth.

Almanak Pers Indonesia. 1995. Departemen Penerangan Republik IndonesiaMasyarakat Pers dan Grafika Indonesia dalam Rahayu, Diktat Mata Kuliah Manajemen Media Massa, Fisipol UGM, Yogyakarta.

Block, Peter (Ed). 2001. Managing in The Media. UK: Planta Tree.

Gopran, Melissa Agnes Dwiputri. 2009. Laporan Akhir Magang Kerja Nyata.

Herman, Edward S., Chomsky, Noam. 1994. Manufacturing Consent: The Political Econimy of the Mass Media. London: Vintage.

Kellner, Douglas. 1990. Television and the Crisis of Democracy. USA: Westview Press. Inc.

Kung, Lucy. 2008. Strategic Management in The Media. London: Sage Publication, Ltd.

Mido, Laura. 2010. Peran produser dalam proses produksi acara Info7 Malang Raya di Batu TV. Surabaya: Jurusan Ilmu Komunikasi UK Petra.

Morissan. 2008. Manajemen Media Penyiaran: Strategi Mengelola Radio dan Televisi. Jakarta: Kencana.

Oktovanni, Princesska. 2009. Laporan Akhir Magang Kerja Nyata: Proses Produksi Acara Kid's Center di Televisi Anak Spacetoon. Surabaya: Jurusan Ilmu Komunikasi UK Petra.

Primasanti, Kartika Bayu. 2007. Rekonsolidasi Potensi Televisi Lokal dalam Penguatan Kapasitas Lokal. Yogyakarta: Fisipol UGM.

Primasanti, Kartika Bayu. 2008. Studi Eksplorasi Rencana Penerapan Sistem Siaran Berjaringan di Indonesia. Yogyakarta: Fisipol UGM.

Proses Produksi Program Acara "Luekoh" Di Arek TV. Surabaya: Jurusan Ilmu Komunikasi UK Petra.

Siregar, Amir Effendi. 1998. Reformasi Pers Indonesia: Biarkan "Bunga” Tumbuh Di Mana-Mana. Suara Pembaruan, Kamis 2 Juli, Jakarta.

Siregar, Ashadi. 2001. Menyingkap Media Penyiaran: Membaca Televisi, Melihat Radio. Yogyakarta: LP3Y.

Sudibyo, Agus. 2004. Ekonomi Politik Media Penyiaran. Jakarta: LKIS.

Tumewu, Linda. 2009. Laporan Akhir Magang Kerja Nyata: Proses Produksi Program ”Our Kidz” SBO TV Surabaya. Surabaya: Jurusan Ilmu Komunikasi UK Petra.

Vane, Edwin T., Gross, Lynne.S. 1994. Programming for TV, Radio, and Cable. Boston: Focal Press. 
172 Jurnal Ilmiah SCRIPTURA, Vol. 3, No. 2, Juli 2009: 161 - 171

Wangsa, Lina Megawati. 2009. Laporan Akhir Magang Kerja Nyata: Tugas dan Tanggung Jawab Produser Dalam Proses Produksi Program "Stasiun Dangdut” di JTV Surabaya. Surabaya: Jurusan Ilmu Komunikasi UK Petra. 